\title{
Food Habits of the Black-tailed Prairie Dog in
}

Western South Dakota

\section{CAROL A. SUMMERS AND RAYMOND L. LINDER}

Highlight: Five major plant species were important in stomach and pellet samples of prairie dogs from two different "towns" in western South Dakota: buffalograss (Buchloe dactyloides), scarlet globemallow (Sphaeralcea coccinea), threadleaf sedge (Carex filifolia), blue grama (Bouteloua gracilis), and western wheatgrass (Agropyron smithii). Seasonal differences for spring and summer diets were not significant $(P>0.05)$. During winter pricklypear cactus (Opuntia polyacantha) and western wheatgrass increased in importance in diets and the other major species declined in importance. Three species important in the range but not important in the diet were threeawn (Aristida fendleriana and $A$. longiseta), prairie dogweed (Dyssodia papposa), and horseweed (Conyza ramosissima).

The black-tailed prairie dog (Cynomys ludovicianus ludovicianus) is characteristic of the short-grass prairie (Koford 1958) and in 1919 occupied about 100 million acres in the United States (Nelson 1919). Early studies concluded that prairie dogs competed with cattle (Nelson 1918; Bell 1920; Taylor 1920), and as a result, a campaign was launched to reduce competition by controlling prairie dogs (Bell 1920). By 1960 (U.S. Dep. of Interior 1963) the number of acres occupied by prairie dogs was reduced to about 1.5 million acres.

The degree of competition between cattle and prairie dogs is not known. Merriam (1901) calculated that forage consumption of one cow was equivalent to that of 257 prairie dogs. Taylor and Loftfield (1924) concluded that the Zuni prairie dog (Cynomys gunnisoni zuniensis) could destroy as much as $80 \%$ of the forage through feeding and clipping vegetation. The objectives of this study were to determine plant species eaten by prairie dogs and to relate the availability of plant species to preference in the feeding habits of prairie dogs.

\section{Study Area}

Two prairie dog towns were studied in southwestern South Dakota. Town 11 is located in the Buffalo Gap National Grasslands adjacent to the Badlands National Monument. Town Burns Basin is located in the Badlands National Monument. Two major vegetative types occurred within the boundaries of both towns.

Composition of the buffalograss vegetative type in Town 11 was mostly grass ( $95 \%$ of the cover). Buffalograss (Buchloe dactyloides) (68\%) and threeawn (Aristida fendleriana and A. longiseta) (12\%) were the most abundant grasses in the summer. The two major grasses on blue grama vegetative type on Town 11 were blue grama

\footnotetext{
Authors are research assistant, Zoology Department, Indiana University, Bloomington and leader, South Dakota Cooperative Wildlife Research Unit, South Dakota State University, Brookings.

The research was supported jointly by the South Dakota Department of Game, Fish and Parks, South Dakota State Univ., the U.S. Bureau of port Fisheries and Wildlife, and The Wildlife Management Institution cooperating.

Manuscript received June 21, 1977
}

(Bouteloua gracilis) (41\% of the cover) and buffalograss (27\%). Forbs made up $14 \%$ of the vegetative cover.

Threeawn (33\%) and buffalograss (19\%) were the important grasses in the threeawn vegetative type of Burns Basin. The important forbs were scarlet globemallow (Sphaeralcea coccinea) (8\%), plaintain (Plantago aristida, P. patagonica, and $P$. spinulosa) (5\%), prairie dogweed (Dyssodia papposa) $(9 \%)$, and horseweed (Conyza ramosissima) (10\%). Plant cover for the dogweed vegetative type on Burns Basin was primarily composed of forbs $(84 \%)$. The two major grass species were threeawn $(7 \%)$ and tumble grass (Schedonnardus paniculatus) $(5 \%)$. The major forb was prairie dogweed $(62 \%)$. Other important forbs were scarlet globemallow (7\%) and plaintain (6\%).

\section{Method}

Stomachs were removed from prairie dogs collected at four randomly selected, active burrows in each vegetative type during two collection periods, May 14-22 and August 1-14, 1973. Forty stomachs were collected in May and 56 in August: five fresh pellets were also collected from each burrow during each collection period. Fourteen stomachs were also obtained from June 24 to July 4, 1973, and eight on December 20, 1973, from Town 11.

Stomach and pellet samples were thoroughly mixed in water for 1 minute, washed over a $0.1-\mathrm{mm}$ screen, and oven dried at $60^{\circ} \mathrm{C}$. Dried stomach and pellet samples were ground over a $1.0-\mathrm{mm}$ screen in a Wiley Mill. Five slides were prepared from each sample using the procedure described by Cavender and Hansen (1970). A compound, binocular microscope at 125 magnification was used to analyze the slides. Twenty locations were observed per slide. A location was considered that area of the slide that was outlined by the microscope field using the prescribed magnification. The initial location on the slide was randomly selected, and the remaining 19 locations were systematically observed. Fragments that were recognized as epidermal tissue were recorded for each location. Individual trichomes that were not adjoined to a fragment of epidermal tissue were disregarded.

Species of grasses and sedges were identified by the occurrence, position (over or between veins), and the shape of such specialized leaf and sheath epidermal structures as macrohairs, microhairs, prickle hairs, papillae, stomata, long cells, short cells, and silica bodies (Summers 1976). Diagnostic characteristics for leaf and stem material of forbs were the occurrence, shape, and position of certain epidermal structures: trichomes, stomata, subsidiary cells, crystals, cell walls, and cuticle. Most leaf and aboveground stem fragments could be recognized using these diagnostic characteristics. However, belowground stem material and root material were impossible to differentiate into species so these plant parts were recorded as "root-stem material." Seed fragments were not divided into species but rather recorded as "seed material."

Frequency percentages were recorded for each plant species, and percentages were converted to relative density as described by Sparks and Malechek (1968). Diet data were summarized as mean dry weight percentages (relative density) for each plant specics in each vegetative type. Mean dry weight percentage for vegetative types did not include root-stem or seed material so that dry weights could be compared with availability (cover percentages) of each species. 
To estimate food availability, vegetation was surveyed at each burrow during the two main collection periods in May and August 1973. Fifteen randomly selected plots $(31 \times 31 \mathrm{~cm})$ were measured in four concentric circles $(3,6,9,12 \mathrm{~m})$ around the burrow. Ocular estimates of plant cover were made for all plant species. Aerial parts of plants were projected onto the surface of the ground. Total plant cover was estimated in addition to coverage of individual species. The percentage of area covered was recorded with a scale from Daubenmire (1959). The midpoint in each class of the scale was used as the estimate for coverage for a species. These values of percentage of total area covered for each species were converted to percentage of plant area covered using the total plant coverage measured in the plot.

\section{Results and Discussion}

A nested analysis of variance (Schultz 1955; Mendenhall $1968)$ showed no significant differences $(P>0.05)$ in the plant taxa of prairie dog stomachs collected from burrows among vegetative types, between vegetative types within towns, and between May and August collection periods. However, contents from stomachs were significantly different between towns $(P<0.05)$. The range survey showed no significant difference $(P>0.05)$ in vegetation among concentric circles; but differences in vegetation were significant $(P<0.05)$ among burrows, between vegetative types, between towns, and between seasons.

Seven plant species made up the major (greater than 5\%) food items in prairie dog stomachs throughout the year (Table 1). Although food habits did not change significantly between spring and summer, a change did occur in December when pricklypear and western wheatgrass were of greater importance.

Grasses made up $65 \%$ of the mean annual diet and forbs $34 \%$. Kelso (1939) reported $62 \%$ grasses and $34 \%$ forbs, with western wheatgrass $(12 \%)$ and sixweeks fescue $(9 \%)$ as the important grasses. He did not find buffalograss, blue grama, or sedge
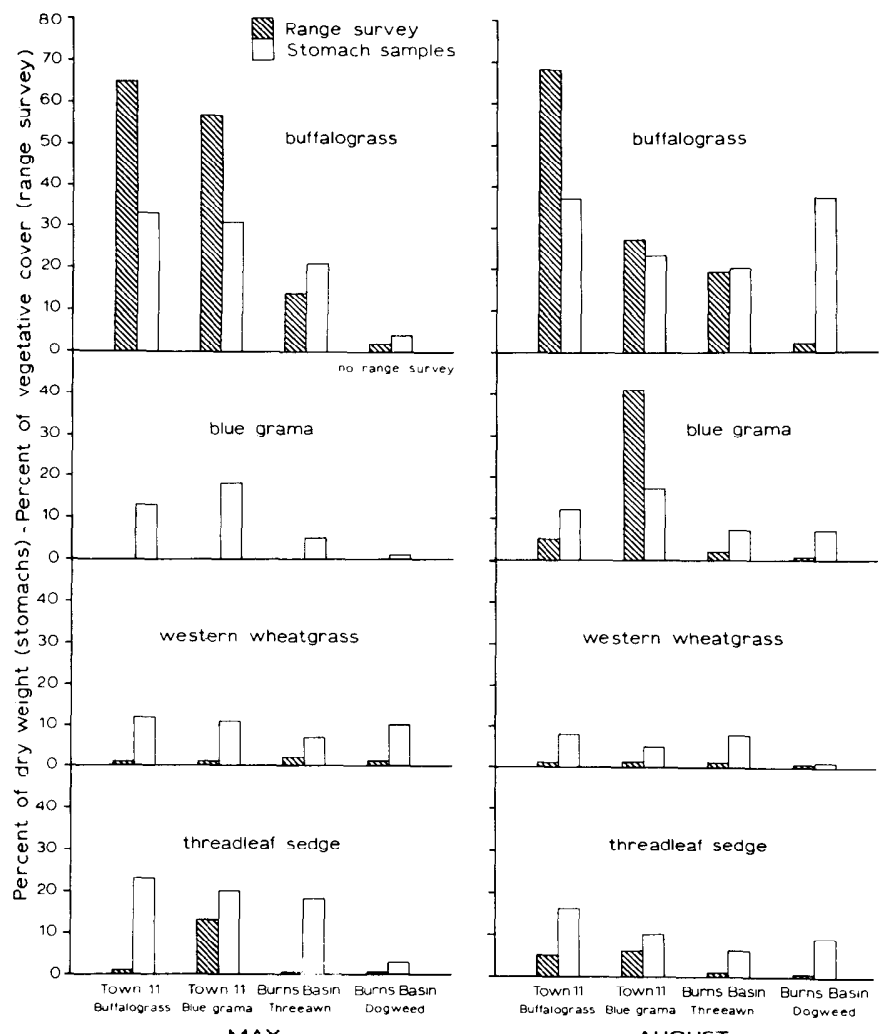

AUGUST

Fig. 1. A. Comparison of the percentage of dry weight of vegetation in stomachs and percentage of vegetative cover in the range survey in the four vegetative covers for May and August.

Table 1. Percentage of dry weight (relative density) for plant species in stomach samples of black-tailed prairie dogs collected from Town 11 and Burns Basin in 1973.

\begin{tabular}{lccccc}
\hline & \multicolumn{5}{c}{ Percent dry weight } \\
\cline { 2 - 6 } Plant species & $\begin{array}{c}\text { December } \\
(8)^{\mathrm{a}}\end{array}$ & $\begin{array}{c}\text { May } \\
(40)\end{array}$ & $\begin{array}{c}\text { June-July } \\
(14)\end{array}$ & $\begin{array}{c}\text { August } \\
(56)\end{array}$ & $\begin{array}{c}\text { Annual } \\
(118)\end{array}$ \\
\hline Total grasses and sedges & 57 & 65 & 74 & 66 & 65 \\
Total forbs & 43 & 35 & 25 & 33 & 34 \\
Major species & & & & & \\
Agropyron smithii & 38 & 10 & 12 & 5 & 16 \\
Bouteloua gracilis & 2 & 9 & 13 & 11 & 9 \\
Buchloe dactyloides & 8 & 22 & 34 & 29 & 23 \\
Carex filifolia & 8 & 16 & 4 & 10 & 9 \\
Opuntia polyacantha & 32 & trb & 1 & 1 & 8 \\
Plantago spp. & 1 & 9 & 5 & 1 & 4 \\
Sphaeralcea coccinea & 11 & 21 & 15 & 26 & 18 \\
Others & 1 & 9 & 16 & 18 & 11 \\
\hline
\end{tabular}

a Sample size in parentheses.

b Trace $=$ less than $1 \%$.

important anytime during the year. Koford (1958), Smith (1958), and Tiletston and Lechleitner (1966) listed western wheatgrass, blue grama, and buffalograss important plant species in the diet during the growing season. Lerwick (1974) in Colorado concluded that $88 \%$ of the diet was composed of grasses and sedges from May through September. Favorite species eaten by prairie dogs were blue grama, needleleaf sedge (Carex eleocharis), dropseed (Sporobolus cryptandrus), and scarlet globemallow (Lerwick 1974). Lerwick (1974) stated that prairie dogs did not consume buffalograss even though it was a dominant grass in the study area. He found that many annual forbs common in the range were not eaten.

Smith (1958), Koford (1958), Tiletston and Lechleitner (1966), and Kelso (1939) mentioned the importance of prickly-

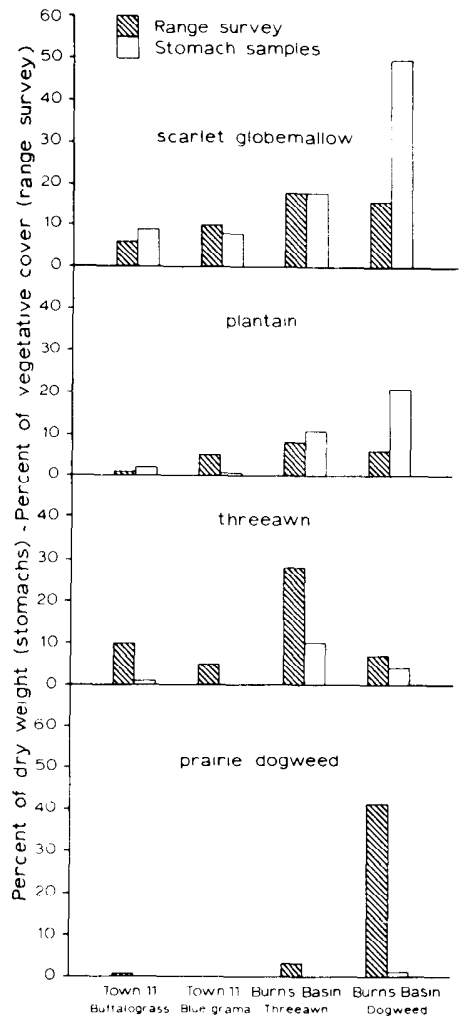

MAY

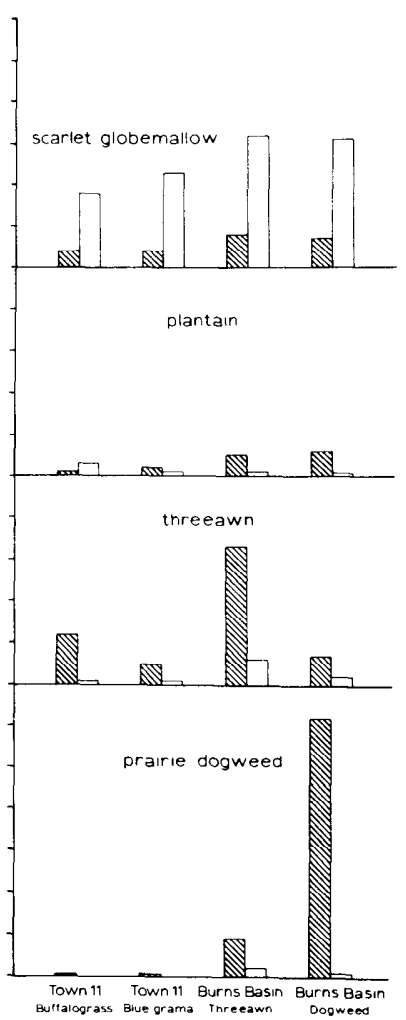

AUGUST
Fig. 2. B. Comparison of the percentage of dry weight of vegetation in stomachs and percentage of vegetative cover in the range survey in the four vegetative covers for May and August. 
Table 2. Percentages of dry weight (relative density) for plant species in stomach and pellet samples collected from town 11 and Burns Basin for May 12-22 and August 1-14, 1973.

\begin{tabular}{|c|c|c|c|c|}
\hline \multirow[b]{3}{*}{ Plant species } & \multicolumn{4}{|c|}{ Percent dry weight } \\
\hline & \multicolumn{2}{|c|}{ Town 11} & \multicolumn{2}{|c|}{ Burns Basin } \\
\hline & $\begin{array}{c}\text { Stomachs } \\
(58)^{\mathrm{a}}\end{array}$ & $\begin{array}{c}\text { Pellets } \\
(16)\end{array}$ & $\begin{array}{c}\text { Stomachs } \\
(38)\end{array}$ & $\begin{array}{l}\text { Pellets } \\
\text { (16) }\end{array}$ \\
\hline Total grasses and sedges & 80 & 95 & 51 & 83 \\
\hline Total forbs & 20 & 5 & 48 & 17 \\
\hline Root-stem and seed material & 6 & 1 & 10 & 1 \\
\hline Buchloe dactyloides & 31 & 28 & 21 & 28 \\
\hline Carex filifolia & 17 & 19 & 9 & 10 \\
\hline Bouteloua gracilis & 15 & 15 & 5 & 6 \\
\hline Sphaeralcea coccinea & 14 & 4 & 33 & 14 \\
\hline Agropyron smithii & 9 & 19 & 7 & 14 \\
\hline Aristida spp. & 1 & 2 & 6 & 9 \\
\hline Munroa squarrosa & 3 & 1 & $\mathrm{tr}^{\mathrm{b}}$ & 4 \\
\hline Schedonnardus paniculatus & 2 & 7 & 2 & 11 \\
\hline Sporobolus cryptandrus & 2 & 3 & 2 & 1 \\
\hline Plantago spp. & 2 & tr & 8 & 1 \\
\hline
\end{tabular}

aSample size in parentheses

$\mathrm{b}_{\text {Trace }}=$ less than $1 \%$.

pear cactus as a green winter food item. This was true in the present study as well. Digging for roots of grasses and forbs in late fall, winter, and early spring was mentioned in each of the studies cited above. We did not find an increase in root-stem material from August to December.

Smith (1958) and Koford (1958) found that seed material became important food items in the summer months. Lerwick (1974) found that seed material on one of his sites became important during the dry period; but, on the other site, seed material remained unimportant. In this study seed material constituted less than $5 \%$ of the stomach contents throughout the seasons studied. Although Smith (1958) and Kelso (1939) mentioned the importance of insects in spring, we found no insect material in the stomachs collected.

When percentage of dry weight in the stomach samples was compared to percentage plant cover for the range survey, it was found that occurrence of plant species in the diet differed from their occurrence in the range. All major plant species except buffalograss occurred more frequently in the diet than they occurred in the range survey (Fig. 1). The prairie dogs did not utilize threeawn, prairie dogweed, and horseweed. These three species were important in Burns Basin vegetative types.

A paired $t$-test (Mendenhall 1968) showed that the differences were not significant $(P>0.05)$ in mean relative densities of plant species between stomach and pellet samples collected from Town 11 and Burns Basin (Table 2). Todd and Hansen (1973) also found no significant differences between rumen and pellet samples of bighorn sheep in Colorado. It appears that pellet samples could be substituted for stomach samples, and a valid index of the important foods would be obtained. However, we evidently underestimated minor species of forbs in pellets. Seventeen minor species of forbs (totaling 6\%) were found in the stomach samples from Burns Basin; pellet samples had five minor species $(2 \%)$. On Town 11,13 minor forb species $(4 \%)$ were found in stomach samples and only 3 species (1\%) in pellet samples.

\section{Conclusions}

In both stomach and fecal pellets, the same five plant species were important for spring and summer in all vegetative types of the two study areas, even though the vegetative composition was different on the areas. The five important species were buffalograss, scarlet globemallow, threadleaf sedge, blue grama, and western wheatgrass. Three species that were important in the range but were not important in feeding were threeawn, prairie dogweed, and horseweed. Insect matter did not occur in the stomachs, and seed material made up less than $5 \%$ of the food material. Results of the study did not differ greatly from other studies except that buffalograss made up the greatest percentage of the stomach contents.

While the importance of pricklypear cactus and western wheatgrass increased during the winter, the importance of buffalograss, blue grama, threadleaf sedge, and scarlet globemallow decreased. Root material occurred in low incidence in all seasons.

\section{Literature Cited}

Bell, W. B. 1920. Death to the rodents. U.S. Dep. Agr. Yearb. 1920:421-438. Cavender, B. R., and R. M. Hansen. 1970. The microscope method used for herbivore diet estimates and botanical analysis of litter and mulch at the Pawnee Site. U.S. Int. Biol. Grasslands Biome Tech. Rep. No. 18. Nat. Res. Ecol. Lab., Fort Collins. 10 p.

Daubenmire, R. 1959. A canopy-method of vegetational analysis. N. W. Sci. 33:43-64.

Kelso, L. H. 1939. Food habits of prairie dogs. U.S. Dep. Agr. Circ. 529. 15 p.

Koford, C. B. 1958. Prairie dogs, white faces, and blue grama. Wildl. Monogr. No. 3.78 p.

Lerwick, A. C. 1974. The effects of the black-tailed prairie dog on vegetative composition and their diet in relation to cattle. MS Thesis. Colorado State Univ., Fort Collins. 106 p.

Mendenhall, W. 1968. Introduction to Linear Models and the Design and Analysis of Experiments. Wadsworth Publishing Co., Inc., Calif. 465 p.

Merriam, C. H. 1901. The prairie dog of the great plains. U.S. Dep. Agr. Yearb. 1901:257-270.

Nelson, E. W. 1918. Annual report of chief of Bureau of Biological Survey. p. 257-275. In: Annual Reports of the Dep. of Agr. for the year ended June 30,1918 .

Nelson, E. W. 1919. Annual report of chief of Bureau of Biological Survey. p. 275-298. In: Annual Reports of the Dep. of Agr. for the year ended June $30,1919$.

Schultz, E. F., Jr. 1955. Rules of thumb for determining expectations of mean squares in analysis of variance. Biometrics. 2:123:135.

Smith, R. E. 1958. Natural history of the prairie dog in Kansas. Univ. Kansas Mus. Nat. Hist. Misc. Pub. No. 9. 39 p.

Sparks, D. R., and J. C. Malechek. 1968. Estimating percentage dry weight in diets using a microscope technique. J. Range Manage. 21:264-265.

Summers, C. A. 1976. Key to microscopic fragments of plant tissue in prairie dog stomachs and food habits of prairie dogs in South Dakota. MS Thesis. South Dakota State Univ., Brookings. $129 \mathrm{p}$.

Taylor, W. P. 1920. Suggestions for ecologic investigations in vertebrate zoology. Sci. 51:283-287.

Taylor, W. P., and J. V. G. Loftfield. 1924. Damage to range grasses by the Zuni prairie dog. U.S. Dep. Agr. Bull. 1227. 15 p.

Tiletston, J. V., and R. R. Lechleitner. 1966. Some comparisons of the blacktailed and white-tailed prairie dogs in north-central Colorado. Amer. Midl. Nat. 75:292-316.

Todd, J. W., and R. M. Hansen. 1973. Plant fragments in the feces of bighorns as indicators of food habits. J. Wildl. Manage. 37:363-365.

U.S. Dep. Interior. 1963. Inventory of areas occupied by prairie dogs in 1961 . Circular letter, Branch of Predator and Rodent Control. U.S. Fish and Wildlife. 